\title{
Andrographolide attenuates skeletal muscle dystrophy in $m d x$ mice and increases efficiency of cell therapy by reducing fibrosis
}

\author{
Daniel Cabrera ${ }^{1,2}$, Jaime Gutiérrez ${ }^{1}$, Claudio Cabello-Verrugio ${ }^{3}$, Maria Gabriela Morales ${ }^{1}$, Sergio Mezzano ${ }^{4}$, \\ Ricardo Fadic ${ }^{5}$, Juan Carlos Casar ${ }^{5}$, Juan L Hancke ${ }^{6}$ and Enrique Brandan ${ }^{1 *}$
}

\begin{abstract}
Background: Duchenne muscular dystrophy (DMD) is characterized by the absence of the cytoskeletal protein dystrophin, muscle wasting, increased transforming growth factor type beta (TGF- $\beta$ ) signaling, and fibrosis. At the present time, the only clinically validated treatments for DMD are glucocorticoids. These drugs prolong muscle strength and ambulation of patients for a short term only and have severe adverse effects. Andrographolide, a bicyclic diterpenoid lactone, has traditionally been used for the treatment of colds, fever, laryngitis, and other infections with no or minimal side effects. We determined whether andrographolide treatment of $m d x$ mice, an animal model for DMD, affects muscle damage, physiology, fibrosis, and efficiency of cell therapy.

Methods: $m d x$ mice were treated with andrographolide for three months and skeletal muscle histology, creatine kinase activity, and permeability of muscle fibers were evaluated. Fibrosis and TGF- $\beta$ signaling were evaluated by indirect immunofluorescence and Western blot analyses. Muscle strength was determined in isolated skeletal muscles and by a running test. Efficiency of cell therapy was determined by grafting isolated skeletal muscle satellite cells onto the tibialis anterior of $m d x$ mice.

Results: $m d x$ mice treated with andrographolide exhibited less severe muscular dystrophy than untreated dystrophic mice. They performed better in an exercise endurance test and had improved muscle strength in isolated muscles, reduced skeletal muscle impairment, diminished fibrosis and a significant reduction in TGF- $\beta$ signaling. Moreover, andrographolide treatment of $m d x$ mice improved grafting efficiency upon intramuscular injection of dystrophin-positive satellite cells.
\end{abstract}

Conclusions: These results suggest that andrographolide could be used to improve quality of life in individuals with DMD.

Keywords: Andrographolide, mdx, DMD, Fibrosis, Skeletal muscle, Cell therapy

\section{Background}

Muscular dystrophies are a group of genetic muscular diseases. The most severe is Duchenne muscular dystrophy (DMD), an X-linked recessive disorder affecting 1 in 3,500 births for which there is no effective therapy [1]. DMD is caused by the absence of dystrophin, a cytoskeletal protein that anchors the muscle fiber to the extracellular matrix

\footnotetext{
* Correspondence: ebrandan@bio.puc.cl

'Centro de Regulación Celular y Patología (CRCP), Centro de Regeneración y Envejecimiento (CARE), Laboratorio de Diferenciación Celular y Patología, Departamento de Biología Celular y Molecular, MIFAB, Pontificia Universidad Católica de Chile, Avenida Libertador Bernardo O'Higgins, 340, Santiago, Chile Full list of author information is available at the end of the article
}

(ECM). The absence of this protein increases susceptibility to muscle fiber rupture caused by the continuous cycles of contraction and relaxation [2,3]. Thus, children with this condition gradually and progressively lose muscle strength, typically requiring the use of a wheel chair from the age of ten and dying in the late second or early third decade of life as a result of cardiorespiratory arrest. One of the causes of muscle damage and loss of function is the development of fibrosis, which is characterized by excessive accumulation of extracellular matrix (ECM) that replaces muscle tissue with connective tissue, dramatically affecting the environment of the fibers and normal muscle physiology [4-9]. 
Pathologic features of DMD include myofiber atrophy, fatty degeneration, necrosis and fibrosis, but only fibrosis has been shown through clinical studies to correlate with poor motor outcome, evaluated by muscle strength and age at loss of ambulation [10]. This finding supports the notion that fibrosis directly contributes to progressive muscle dysfunction and the lethal phenotype of DMD [6]. Therefore, the development of new drugs and therapies with anti-fibrotic activity is crucial.

Andrographolide, a bicyclic diterpenoid lactone, is the major constituent of Andrographis paniculata, a plant indigenous to Southeast Asian countries that has been used as an official herbal medicine in China for many years [11]. Traditionally, it is used for the treatment of colds, fever, laryngitis, and other infections, with no or minimal side effects. It has been reported to be particularly efficient at regulating immune responses $[12,13]$ and possesses anti-inflammatory properties by reducing the generation of reactive oxygen species in human neutrophils [11]. Andrographolide not only regulates inflammation, but is also effective against the fibrotic pathology observed in chronic liver and kidney diseases [14-16]. Mechanistically, andrographolide forms a covalent adduct with NF- $\mathrm{kB}$, thus blocking the binding of NF- $\mathrm{kB}$ to nuclear proteins [17]. NF- $\mathrm{kB}$ is an important transcription factor in the progression of skeletal muscular dystrophic diseases [18-20].

Because dystrophic disorders such as DMD have genetic origins there is a great effort to restore gene expression through gene and/or cell therapies. Nevertheless, these therapies represent a major challenge because muscle is the most abundant tissue in the body. Moreover, fibrosis strongly reduces the efficacy of these approaches $[6,9,21]$, therefore, even if current trials are successful, they are unlikely to elicit a significant benefit when extended to people with more advanced stages of the disease and enhanced fibrosis [21,22]. Therefore, understanding the cellular and molecular mechanisms underlying muscle fibrogenesis associated with muscular dystrophies is critical to the development of an effective anti-fibrotic therapy for this type of disease.

In this study, we investigated the effects of andrographolide on the onset of dystrophy in $m d x$ mice, an animal model used to study DMD. We demonstrated that andrographolide treatment of dystrophic mice prevented damage and fibrosis progression as reflected by reduced collagen and fibronectin deposition through a mechanism that involves a decrease in the expression of transforming growth factor type beta (TGF- $\beta$ ) and its downstream mediator connective tissue growth factor (CTGF/CCN2). The reduction of fibrosis was associated with enhanced muscle strength and improved exercise performance. Finally, we determined that the use of andrographolide increased the efficiency of cell therapy through fibrosis reduction.

\section{Methods}

\section{Animals and experimental exercise}

We used 12-week-old control or $m d x$ male mice of the C57BL/10 ScSn strain. The animals were kept at room temperature with a 24-hour night-day cycle and were fed with pellets and water ad libitum. Experimental exercise involved running the mice on a treadmill three times per week for 30 minutes each session at $12 \mathrm{~m} /$ minute over three or four months [6,23-25]. Two experimental groups were designed: animals in the first group were injected intraperitoneally (ip) with andrographolide $(1.0 \mathrm{mg} / \mathrm{kg} / \mathrm{day})$ and animals in the second group were treated with vehicle alone. At the end of the experiment the muscles were dissected and removed under anesthesia (isofluorane gas) and then the animals were sacrificed. Tissues were used for electrophysiological measurement or rapidly frozen and stored at $-80^{\circ} \mathrm{C}$ until processing. All protocols were conducted in strict accordance with guidelines and with the formal approval of the Animal Ethics Committee of the Pontificia Universidad Católica de Chile.

\section{Skeletal muscle histology}

Muscle architecture and histology were analyzed by H\&E staining of transverse sections of muscle [6,26-28].

\section{Evans blue dye (EBD) uptake}

Animals were sacrificed 24 hours after injection with EBD (1\% in PBS). The tibialis anterior (TA) muscles were snapfrozen in isopentane, sectioned in 7- $\mu \mathrm{m}$ cryosections, and fixed in $4 \%$ paraformaldehyde [6]. Muscle cross-sections were visualized under a Nikon Diaphot Eclipse-600 (Nikon, Melville, NY, USA) inverted microscope equipped for epifluorescence. The percentage of EBD-positive fibers was manually counted in a blinded manner [29].

\section{Serum creatine kinase measurement}

Mice were anesthetized and blood was obtained from the periorbital vascular plexus directly into $70 \mu \mathrm{l} \mathrm{micro-}$ hematocrit tubes (Fisher Scientific, Loughborough, UK). Serum was obtained by allowing the blood to clot at room temperature for 30 minutes followed by centrifugation at $1,700 \times \mathrm{g}$ for ten minutes. Serum creatine kinase (CK) was measured using an enzymatic system (Valtek, Santiago, Chile) according to the manufacturer's instructions [6].

\section{Immunoblot analysis}

Muscles were homogenized in ten volumes of TrisEDTA buffer with $1 \mathrm{mM}$ PMSF as described previously [26]. Briefly, protein concentration in aliquots of muscle extract was determined using the bicinchoninic acid protein assay kit (Pierce, Rockford, IL, USA) using BSA as a standard. Aliquots (50 to $100 \mu \mathrm{g}$ ) were subjected to SDS gel electrophoresis in $8 \%$ or $10 \%$ polyacrylamide gels, 
electrophoretically transferred onto PVDF membranes (Schleicher \& Schuell, Keene, NH, USA), and probed with specific antibodies against fibronectin (Sigma, St. Louis, MO, USA), collagen III (Rockland, Gilbertsville, PA USA) and GAPDH (Millipore, Billerica, MA, USA), tubulin (Sigma, St. Louis, MO, USA) as described previously [6]. All immunoreactions were visualized using an enhanced chemiluminescence kit (Pierce, Rockford, IL, USA). Densitometric analysis and quantification were performed using ImageJ software (NIH, Bethesda, MD, USA) [25].

\section{Immunofluorescence microscopy}

For immunofluorescence, $7-\mu \mathrm{m}$ cryosections were fixed in $4 \%$ paraformaldehyde, blocked for one hour in $10 \%$ goat serum in PBS and incubated for one hour at room temperature with specific antibodies against fibronectin (Sigma, St. Louis, MO, USA), collagen I (Chemicon, Temecula, CA, USA), F4/80 (Abcam, Cambridge, MA, USA), p-Smad-2 (Abcam, Cambridge, MA, USA), and dystrophin (Santa Cruz Biotechnology, Santa Cruz, CA, USA). FITC-conjugated goat anti-rabbit IgG and rabbit anti-mouse IgG (Invitrogen, Carlsbad, CA, USA) were used as secondary antibodies. For monoclonal anti-mouse antibodies, all incubations were performed with mouse IgG-blocking solution from the MOM kit (Vector Lab, Burlingame, CA, USA) diluted in $0.01 \%$ Triton X-100/ PBS. For nuclear staining, sections were incubated with $1 \mu \mathrm{g} / \mathrm{ml}$ Hoechst 33258 in PBS for ten minutes. After rinsing, the coverslips were mounted using Fluoromount (Dako, Carpinteria, CA, USA) and observed under a Nikon Diaphot inverted microscope equipped for epifluorescence [26].

\section{NF-кB detection in vivo by Southwestern blotting}

Synthetic sense DNA 5'-AGTTGAGGGGACTTTCCCAGGC-3', which contains a consensus sequence for $\mathrm{NF}-\mathrm{kB}$, was used as the probe. After annealing with complementary DNA $\left(80^{\circ} \mathrm{C}\right.$ for two minutes), the probe was labeled with digoxigenin (DIG) oligonucleotide 3 ' -end labeling (Boehringer Mannheim, Mannheim, Germany). Paraffin-embedded muscle sections were dewaxed, rehydrated, and fixed with $0.2 \%$ paraformaldehyde for $30 \mathrm{mi}$ nutes at $28^{\circ} \mathrm{C}$. Sections were subsequently digested with $433 \mathrm{U} / \mathrm{mg}$ pepsin A (Sigma, St. Louis, MO, USA), washed twice with buffer $1(10 \mathrm{mmol} / \mathrm{L}$ HEPES, $40 \mathrm{mmol} / \mathrm{L} \mathrm{NaCl}$, $10 \mathrm{mmol} / \mathrm{L} \mathrm{MgCl}_{2}, 1 \mathrm{mmol} / \mathrm{L} \mathrm{DTT}, 1 \mathrm{mmol} / \mathrm{L}$ EDTA, $0.25 \% \mathrm{BSA}, \mathrm{pH} 7.4$ ), treated with $0.1 \mathrm{mg} / \mathrm{mL}$ DNase I and washed with buffer $2(10 \mathrm{mmol} / \mathrm{L}$ HEPES, $40 \mathrm{mmol} / \mathrm{L}$ $\mathrm{NaCl}, 1 \mathrm{mmol} / \mathrm{L}$ DTT, $10 \mathrm{mmol} / \mathrm{L}$ EDTA, 0.25\% BSA, $\mathrm{pH} 7.4)$ to stop the reaction. Labeled probe $(100 \mathrm{pmol} / \mathrm{L})$ diluted in buffer 1 containing $0.5 \mathrm{mg} / \mathrm{mL}$ poly dl-dC (Pharmacia, New York, NY, USA) was applied overnight at $37^{\circ} \mathrm{C}$. After washing, sections were incubated for one hour in blocking solution (0.01× SSC, $0.01 \%$ SDS, $0.03 \%$ Tween 20, $0.1 \mathrm{~mol} / \mathrm{L}$ maleic acid, $0.15 \mathrm{~mol} / \mathrm{L}$ $\mathrm{NaCl}, \mathrm{pH} 7.5)$ and then overnight at $4{ }^{\circ} \mathrm{C}$ with rabbit anti-digoxigenin antibody (1:250 in blocking solution; Invitrogen, Carlsbad, CA, USA). The samples were washed and incubated with a secondary Alexa fluor 568 anti-rabbit antibody (Invitrogen, Carlsbad, CA, USA). Nuclear staining with Hoechst 33258 was performed as described above. We used the following negative controls: (a) absence of probes, (b) DIG-labeled mutant NF- $\mathrm{KB}$ probe (sense: $5^{\prime}$ AGTTGAGGCTCCTTTCCCAGGC-3'), at the same concentration as labeled probe, (c) competition assays with 100 -fold excess of unlabeled NF- $\mathrm{B}$ p probe, followed by incubation with the respective labeled probe [30].

\section{RNA isolation and quantitative real-time PCR analysis}

During tissue collection, one TA muscle from each animal was rapidly frozen in liquid nitrogen and used for RNA isolation. Total RNA was isolated with TRIzol reagent according to the manufacturer's protocol (Invitrogen, Carlsbad, CA, USA). Total RNA (500 ng) from each sample was reverse transcribed to cDNA using Super Script Reverse Transcriptase II (Invitrogen, Carlsbad, CA, USA). Quantitative real-time PCR (qPCR) reactions were performed using SYBR Green Master Mix (Bio-Rad, Hercules, CA, USA). Levels of TGF- $\beta$ and CTGF were determined as described before [31]. The real-time amplification of genes was measured with the iCycler thermocycler system and iQ5 optical system software (Bio-Rad, Hercules, CA, USA) [32].

\section{Contractile properties}

The isometric force of isolated muscles was measured as described previously $[6,25,26]$. Briefly, optimum muscle length (Lo) and stimulation voltage were determined from micromanipulation of muscle length to produce maximum isometric twitch force. Maximum isometric tetanic force (Po) was determined from the plateau of the frequency-force relationship after successive stimulations at 1 to $200 \mathrm{~Hz}$ for $450 \mathrm{~ms}$, with two-minute rests between stimuli. After determination of isometric contractile properties, muscles were subjected to a three repeated tetanic stimulation protocol. Muscles at Lo were maximally stimulated for $450 \mathrm{~ms}$ once every five seconds. After functional testing, muscles were removed from the bath, trimmed of their tendons and any adhering non-muscle tissue, blotted once on filter paper and weighed [33-35]. Muscle mass and Lo were used to calculate specific net force (force normalized per total muscle fiber cross-sectional area (CSA), $\left.\mathrm{mN} / \mathrm{mm}^{2}\right)[6,26]$.

\section{Running test}

Mice were subjected to a running test for 15 minutes at $15 \mathrm{~m} /$ minute on a treadmill. The number of times that 
mice were retarded to the first one third of the moving platform (detentions) was counted [6,25].

\section{Single myofiber isolation and satellite cell grafting}

Single myofibers were isolated essentially as described previously [6,36]. Briefly, extensor digitorum longus (EDL) and soleus muscles from six-week-old C57-BL10 mice were dissected and digested in $0.2 \%(\mathrm{w} / \mathrm{v})$ collagenase type 1 (Sigma, St. Louis, MO, USA) in DMEM (Gibco, Grand Island, NY, USA) with $4 \mathrm{mM}$ L-glutamine (Sigma, St. Louis, MO, USA) and 1\% penicillin and streptomycin solution (Sigma, St. Louis, MO, USA) for 90 minutes in a $37^{\circ} \mathrm{C}$ water bath. Satellite cells were separated from the myofibers by physical trituration using the method of Collins et al. [36]. The isolated intact fibers were suspended in $10 \mathrm{ml}$ of complete medium and triturated with a $19 \mathrm{G}$ needle mounted on a $1 \mathrm{ml}$ syringe. The suspension was sequentially passed through a $70-\mu \mathrm{m}$ and $40-\mu \mathrm{m}$ cell sieve (BD Biosciences, San Jose, CA, USA) to remove debris. The satellite cell suspension was centrifuged for 15 minutes at $450 \times \mathrm{g}$. The pellet was resuspended in physiologic serum $(0.9 \% \mathrm{NaCl})$. An aliquot was stained with $1 \mu \mathrm{g} / \mathrm{ml}$ Hoechst and $1 \mu \mathrm{g} / \mathrm{ml}$ cholera toxin subunit B conjugated to Alexa Fluor 488 (Invitrogen, Carlsbad, CA, USA) for five minutes, washed with PBS and incubated with trypan blue. Cells were counted using a hemocytometer. Doublestained cells that exclude trypan blue were counted as viable cells and the concentration of cells was adjusted to 25 cells $/ \mu$ l. To confirm the purity of the isolated satellite cells, an aliquot was seeded onto Matrigel $(1 \mathrm{mg} / \mathrm{ml})$ (Sigma, St. Louis, MO, USA) and cultured overnight in complete medium for 18 hours before immunocytochemistry for myogenic markers. For grafting, 500 satellite cells were grafted into both TA muscles of seven-month-old $m d x$ mice in a C57-BL10 background under anesthesia using an 8-mm $30 \mathrm{G}$ needle under microscopic observation. The number of dystrophin positive fibers was determined as described previously [6].

\section{Determination of the grafted-satellite cell survival}

The determination of the survival of the grafted satellite cells was performed as previously described [6]. Briefly, 500 freshly isolated satellite cells from a C57-EGFP mice, as described in the previous section, were grafted into both TA muscles of seven-month-old $m d x$ mice in a C57-BL10 background under anesthesia using an 8-mm $30 \mathrm{G}$ needle under microscopic observation. The muscle genomic DNA was extracted with a DNA purification kit (QiAamp DNA from Quiagen). Then the purified DNA were subjected to amplification by real time PCR using TaqMan PCR Universal Master Mix, in an Illumina Eco real time PCR (Illumina, USA), Primer and Taqman probe for EGFP and b-actin (endogenous control) were from Applied Biosystems, (USA).

\section{Statistics}

The statistical significance of differences between the means of the experimental groups was evaluated using one-way analysis of variance (ANOVA) with a post hoc Bonferroni multiple-comparison test or two tailed $t$-tests (Prism 3.0, GraphPad, San Diego, CA, USA). A difference was considered statistically significant at $P<0.05$.

\section{Results}

Andrographolide treatment improves histology and reduces muscle damage in dystrophic skeletal muscle

To determine whether andrographolide has an effect on the dystrophic phenotype of $m d x$ mice, we evaluated the histology of the TA muscle from andrographolide and vehicle-treated $m d x$ mice by $H \& E$ staining. Administration of andrographolide to $m d x$ mice for three months reduced the increase in infiltrating cells and necrotic areas and showed a clear improvement in muscle histopathology compared with vehicle-treated $m d x$ mice (Figure 1A, two different magnifications). To specifically evaluate damage at the $m d x$ sarcolemma, we used the EBD uptake protocol [29]. Lower EBD uptake was observed in the muscle fibers from $m d x$ mice treated with andrographolide compared with control $m d x$ fibers, suggesting less muscle damage (Figure 1B). Concordantly, serum CK levels were decreased in andrographolide-treated $m d x$ compared with control $m d x$ mice, with an approximately $50 \%$ recovery score [37] (Figure 1C). Table 1 shows quantification of areas of necrosis and regeneration [38]. Administration of andrographolide to $m d x$ decreased cumulative damage. We did not find any differences in the minimal Feret's diameter between $m d x$ mice treated with andrographolide and $m d x$ mice treated with vehicle (Additional file 1: Figure S1). These results indicate that treatment of $m d x$ mice with andrographolide improves the architecture of dystrophic skeletal muscles and decreases tissue damage.

\section{Fibrosis in dystrophic skeletal muscle is reduced by andrographolide treatment}

Development of fibrosis in dystrophic skeletal muscle is characterized by an increase in ECM compounds such as fibronectin and several types of collagen $[4,6,25,39]$. We evaluated the effect of andrographolide on the level of fibrotic protein in skeletal muscle of dystrophic $m d x$ mice. Immunofluorescence staining of TA muscles from $m d x$ mice treated with andrographolide revealed a large decrease in the accumulation of collagen type III (Figure 2, upper panels) and fibronectin (Figure 2, lower panels). Western blot analysis of the same muscles indicated that andrographolide treatment decreased fibronectin and collagen III protein levels (Figure $3 \mathrm{~A}$ and $\mathrm{B}$ ). We also evaluated andrographolide treatment decrease in fibrosis in gastrocnemius of exercised $m d x$ mice and in diaphragm from non-exercised animals, since diaphragm is the most 

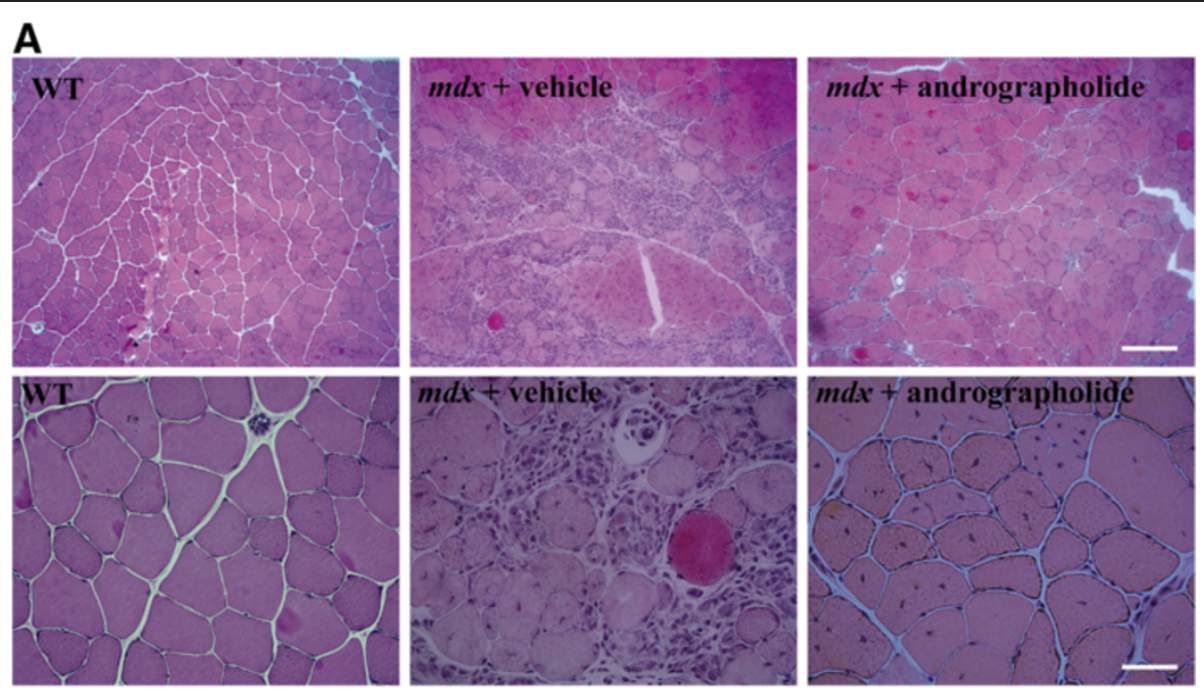

B
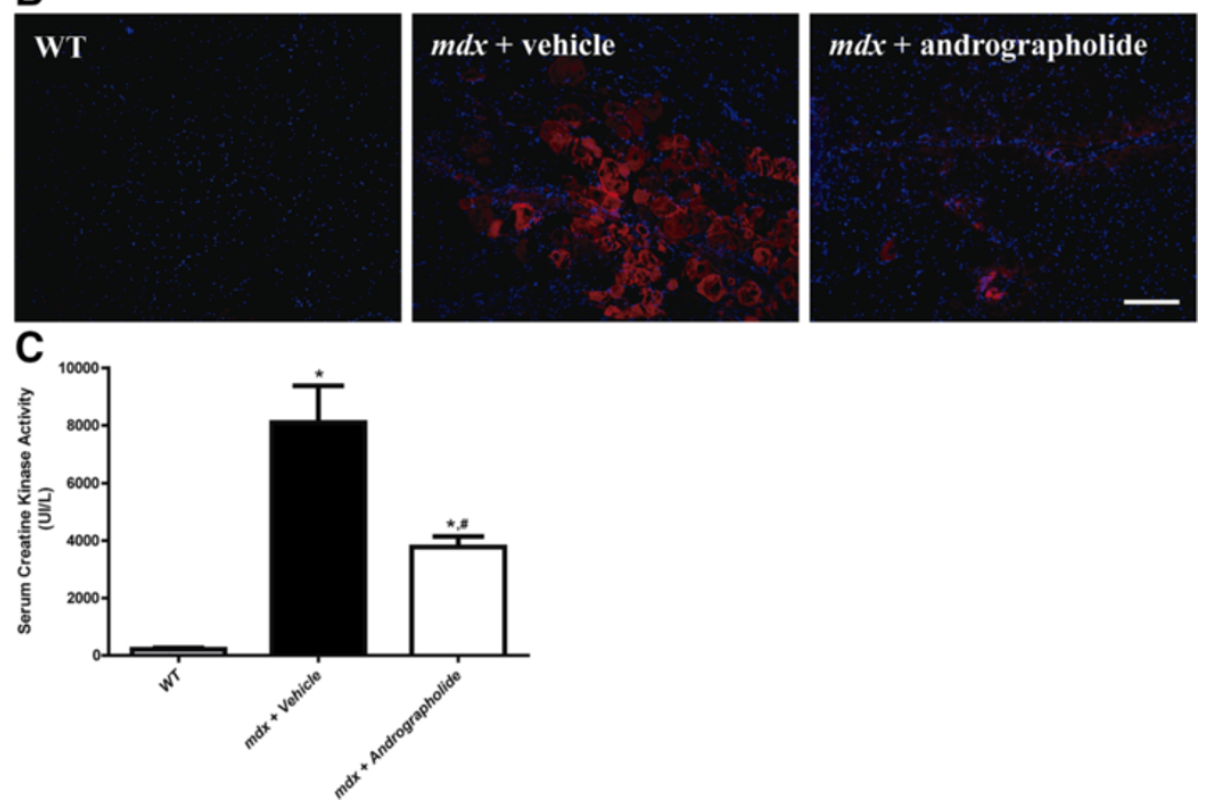

Figure 1 Andrographolide reduces skeletal muscle damage in $m d x$ mice. To augment the extent of muscle fibrosis, three-month-old $m d x$ mice were subjected to an exercise protocol for three months [6,25]. During this period, mice were treated with $1 \mathrm{mg} / \mathrm{kg}$ andrographolide or vehicle (intraperitoneal (ip) injections three times per week, six animals per group). (A) H\&E staining of tibialis anterior (TA) muscles showed a striking reduction in the damaged areas of muscle in andrographolide-treated mdx mice compared with untreated mdx mice. Upper panel shows 100X magnification pictures (scale bars $=200 \mu \mathrm{m}$ ), while the bottom panel shows 400X magnification pictures (scale bars $=50 \mu \mathrm{m}$ ). (B) Evans blue dye uptake in TA muscle fibers from wild type (WT), vehicle-treated $m d x$ mice, and andrographolide-treated mdx mice. Nuclei were labeled with Hoechst. Mice were injected ip with 1\% Evans blue dye 24 hours before muscle fixation (scale bar $=200$ Mm). (C) Serum creatine kinase (CK) was measured to evaluate skeletal muscle damage. The bar graph shows a significant reduction in serum CK activity in andrographolide-treated $m d x$ mice compared with vehicle-treated $m d x$ mice. Values are expressed as mean \pm SD of three independent experiments, using five mice for each experimental condition. $(* P<0.05$ relative to $W T$ mice; $\# P<0.05$ relative to vehicle-treated $m d x$ mice). The recovery score was $49.5 \%$.

Table 1 Cumulative muscle damage in exercised $m d x$ mice treated or not with andrographolide

\begin{tabular}{lccr}
\hline & Necrosis & Regeneration & Cumulative damage \\
\hline$m d x+$ vehicle & $7.63 \pm 0.85$ & $42.14 \pm 4.03$ & $49.77 \pm 4.61$ \\
$m d x+$ andrographolide & $4.14 \pm 0.51^{\mathrm{b}}$ & $30.23 \pm 2.86^{\mathrm{a}}$ & $34.37 \pm 2.97^{\mathrm{a}}$ \\
\hline
\end{tabular}

Cumulative skeletal muscle damage in $m d x$ mice consists of active myofiber necrosis plus the areas of subsequent regeneration (new myofibers). Values shown are average percentage (\%) of whole cross-sectional area + - SEM (values were analyzed by a $t$-test, $n=5,{ }^{a} P<0.05$ ) [38]. ${ }^{b} P<0.01$. 

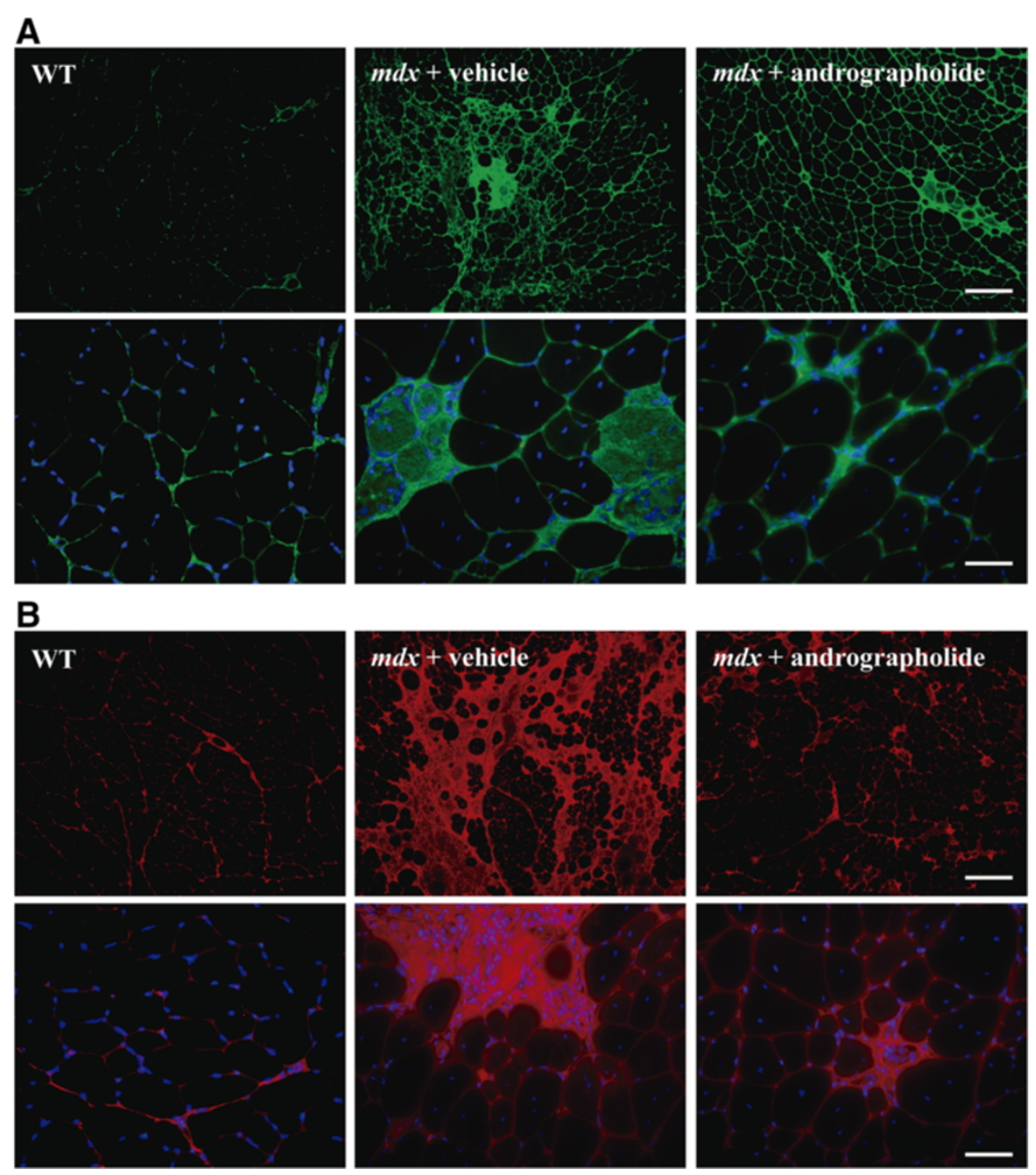

Figure 2 Andrographolide reduces skeletal muscle fibrosis in $\mathbf{m d x}$ mice. Fibrosis was augmented as explained in the legend of Figure 1. During this period, mice were treated with $1 \mathrm{mg} / \mathrm{kg}$ andrographolide or vehicle (intraperitoneal (ip) injections three times per week, six animals per group). Indirect immunofluorescence analysis of (A) collagen I (green) and (B) fibronectin (red) in cryosections of tibialis anterior (TA) muscles from wild type (WT), vehicle-treated $m d x$ mice, and andrographolide-treated $m d x$ mice. Nuclei are stained in blue (Hoechst). Bar corresponds to 200 and $50 \mu \mathrm{m}$ for 100X and 400X magnification pictures respectively.

damaged muscle in $m d x$ mice and is not clearly affected by exercise [6,25]. Additional file 2: Figure S2 shows a decrease in fibrosis and damage determined by collagen type I staining and H\&E respectively. Together, these results suggest that the treatment of $m d x$ mice with andrographolide decreases the accumulation of fibrotic proteins in different skeletal muscle groups. Together, these results suggest that the treatment of $m d x$ mice with andrographolide decreases the accumulation of fibrotic proteins.

\section{Andrographolide reduces the activity of NF- $\mathrm{KB}$ in vivo}

Because andrographolide is a specific NF- $\mathrm{kB}$ inhibitor [17], we evaluated the in vivo activity of NF-kB in skeletal muscle of andrographolide-treated $m d x$ mice by Southwestern blotting [30]. The results showed that NF- $\mathrm{\kappa B}$ activity was increased in $m d x$ TA compared with the corresponding wild type (WT) samples. In contrast, treatment with andrographolide reduced the number of nuclei positive for NF-kB in $m d x$ TA skeletal muscle (Figure 4A and $\mathrm{B}$ ). This result shows that andrographolide reduces the activity of NF-kB in skeletal muscle in vivo.

\section{Andrographolide reduces the level of the pro-fibrotic} factor TGF- $\beta$ and the downstream Smad-dependent signaling pathway in $m d x$ skeletal muscles

TGF- $\beta$ is an important pro-fibrotic factor and the downstream Smad-dependent signaling pathway is augmented in $m d x$ skeletal muscle $[6,40,41]$. Therefore, we evaluated whether andrographolide modulated the in vivo expression of TGF- $\beta$. Concordant with the decrease in fibrosis, TGF- $\beta$ 


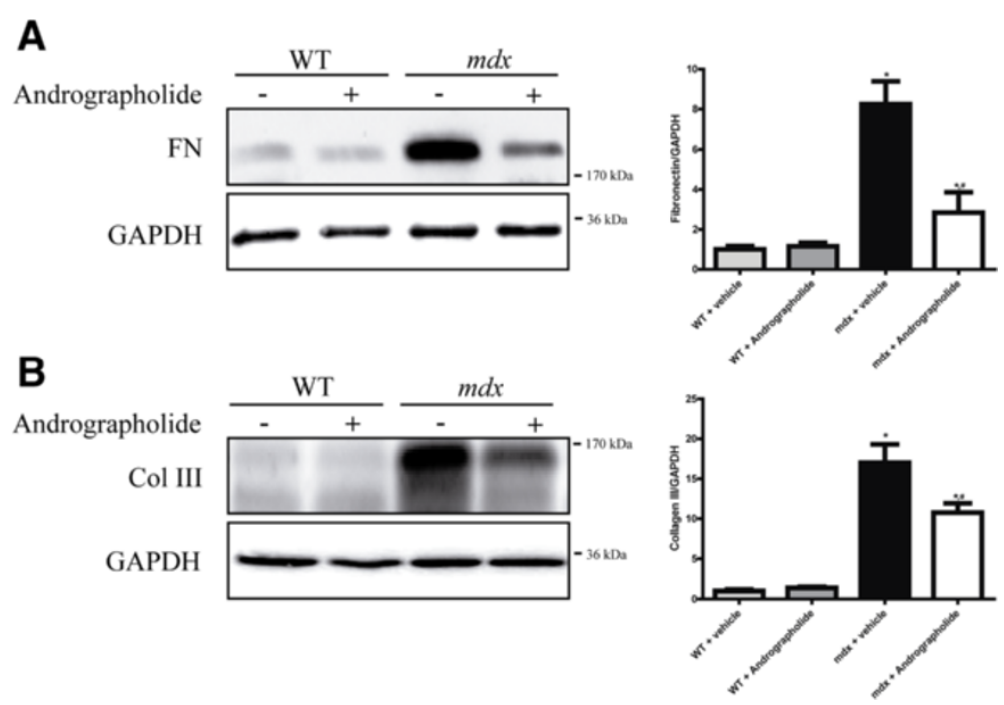

Figure 3 Andrographolide reduces the amount of fibrotic proteins in $\boldsymbol{m d x}$ skeletal muscle. Experiments were performed as explained in the legend of Figure 2. Muscle extracts were obtained under each experimental condition and fibrotic proteins were analyzed by western blotting. (A) Fibronectin (FN) and (B) collagen type III (Col III) from tibialis anterior (TA) muscles of wild type (WT), vehicle-treated mdx mice, and andrographolide-treated $m d x$ mice. GAPDH protein levels are shown as loading control; molecular weight markers are shown in $\mathrm{kDa}$. Values are expressed as mean \pm SD of three independent experiments, using three mice for each experimental condition. ${ }^{*} P<0.05$ relative to WT mice; $\# P<0.05$ relative to vehicle-treated $m d x$ mice).

expression determined by qPCR was reduced in $m d x$ mice as a consequence of andrographolide treatment (Figure 5A). We then evaluated the expression levels of CTGF and collagen type I, two downstream pro-fibrotic factor [6,26,42] and showed that expression levels of CTGF and collagen type I in dystrophic skeletal muscle were also reduced by andrographolide treatment (Figure $5 \mathrm{~B}$ and $\mathrm{C}$ ).

We then determined whether the decrease in TGF- $\beta$ expression following andrographolide treatment was reflected in diminished activity of the Smad-dependent signaling pathway. Immunofluorescence localization of phosphorylated Smad-2 and Smad-3 proteins (p-Smad-2 and $\mathrm{p}$-Smad-3) in TA muscle sections indicated that andrographolide treatment reduced the number and the proportion of nuclei positive for both phosphorylated Smad proteins in TA of $m d x$ mice (Figure 6). Additional file 3: Figure $\mathrm{S} 3$ shows the localization of $\mathrm{p}-\mathrm{Smad}-3$ in consecutive Sections. p-Smad-3 positive reaction is found mainly in necrotic-regenerating areas, likely corresponding to interstitial cells but also in nuclei inside regenerated fibers. Andrographolide treatment suggests a higher reduction in interstitial cells compared to regenerating muscle fibers. Collectively, these results show that andrographolide treatment reduced both the expression and activity of TGF- $\beta$ in $m d x$ skeletal muscle.

\section{Andrographolide treatment improves skeletal muscle strength and exercise performance in $\mathrm{mdx}$ mice} We then evaluated whether andrographolide treatment of $m d x$ mice had an impact on the skeletal muscle physiology that determines contractile strength in isolated TA muscles. Andrographolide-treated $m d x$ mice showed a significant increase in the generation of isometric force compared with vehicle-treated $m d x$ mice at frequencies ranging between 50 and $100 \mathrm{~Hz}$ (Figure 7A). Twitch and tetanic force also showed a higher strength in the TA muscle from andrographolide-treated $m d x$ mice (Figure 7B and $\mathrm{C}$ respectively). Given that andrographolide treatment improves muscle strength in single isolated dystrophic muscles, we asked whether andrographolide treatment similarly affects the whole body muscle performance when $m d x$ mice are challenged in a treadmill running protocol. To address this question, we performed a functional test of exercise endurance through continuous exercise [23-25]. Mice treated with andrographolide showed an enhanced performance, as determined by a significant decrease in the number of detentions in the treadmill running protocol (Figure 7D). Together, these results indicate that andrographolide improves skeletal muscle strength and endurance.

\section{Reduction of fibrosis by andrographolide improves the efficiency of in vivo cell therapy}

Because we observed an accumulation of fibroblasts in non-fibrotic areas of skeletal muscle from andrographolide-treated $m d x$ mice, we evaluated whether cell therapy using muscle precursor cells was improved in the andrographolide-treated mice. Freshly purified satellite cells from isolated single myofibers from WT mouse donors were grafted into both TA muscles of seven- 

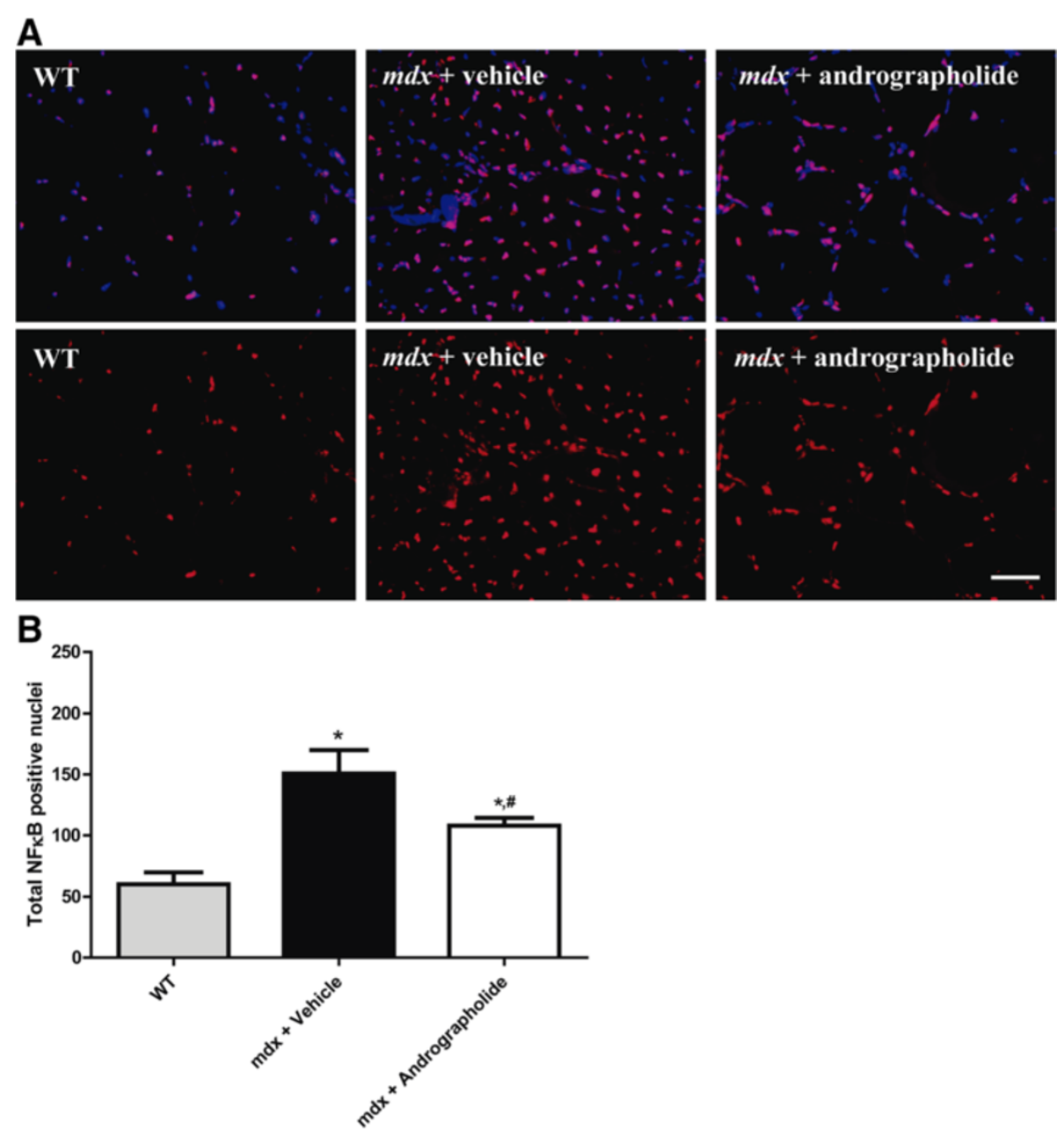

Figure 4 Andrographolide decreases NF-KB activity in vivo. Fibrosis was augmented as explained in the legend of Figure 1. During this period, mice were treated with $1 \mathrm{mg} / \mathrm{kg}$ andrographolide or vehicle (intraperitoneal (ip) injections three times per week, six animals per group). The activity of NF-KB was evaluated in formalin-fixed muscle samples by Southwestern blot analysis. A specific DNA was used to detect active NF-KB by immunofluorescence (red). The nuclei were stained with Hoechst (blue). (A) The upper panel shows merged red (active NF-KB) and blue (total nuclei) signals. Bar corresponds to $50 \mu \mathrm{m}$. (B) Quantification of total nuclei per field (in 400X magnification pictures).
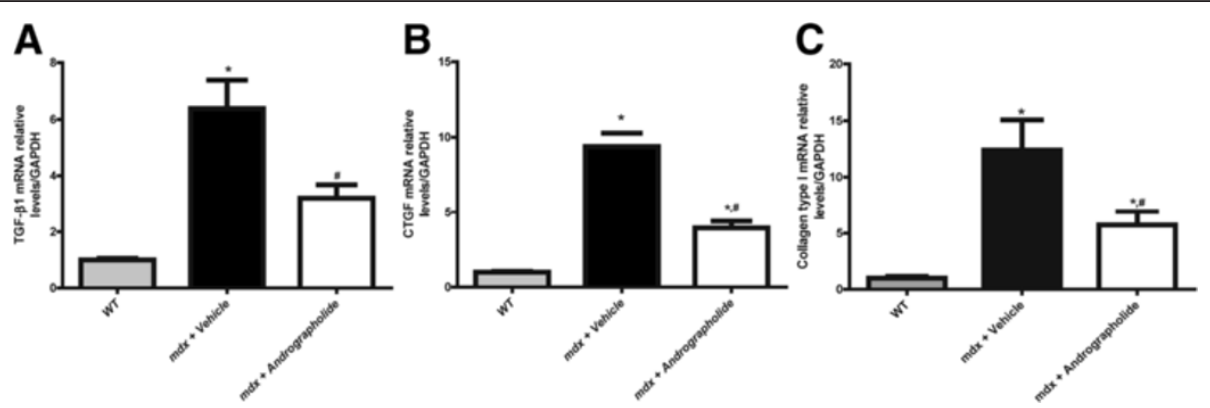

Figure 5 Andrographolide reduces expression of pro-fibrotic factors and collagen type I in $\mathbf{m d x}$ mice. Fibrosis was augmented as explained in the legend of Figure 1. During this period, mice were treated with $1 \mathrm{mg} / \mathrm{kg}$ andrographolide or vehicle (intraperitoneal (ip) injections three times per week, four animals per group). (A) Transforming growth factor type beta (TGF- $\beta 1$ ), (B) Connective tissue growth factor (CTGF) and (C) collagen type I mRNA levels were determined in tibialis anterior (TA) muscle from wild type (WT), vehicle-treated mdx mice, and andrographolide-treated $m d x$ mice by qPCR using GAPDH as a reference gene. Values correspond to the mean dCT value \pm SD of three independent experiments, normalized to WT levels $(* P<0.05$ relative to WT mice; $\# P<0.05$ relative to vehicle-treated $m d x$ mice). The recovery scores for TGF- $\beta 1$ and CTGF were $56.3 \%$ and 63.2 respectively. 

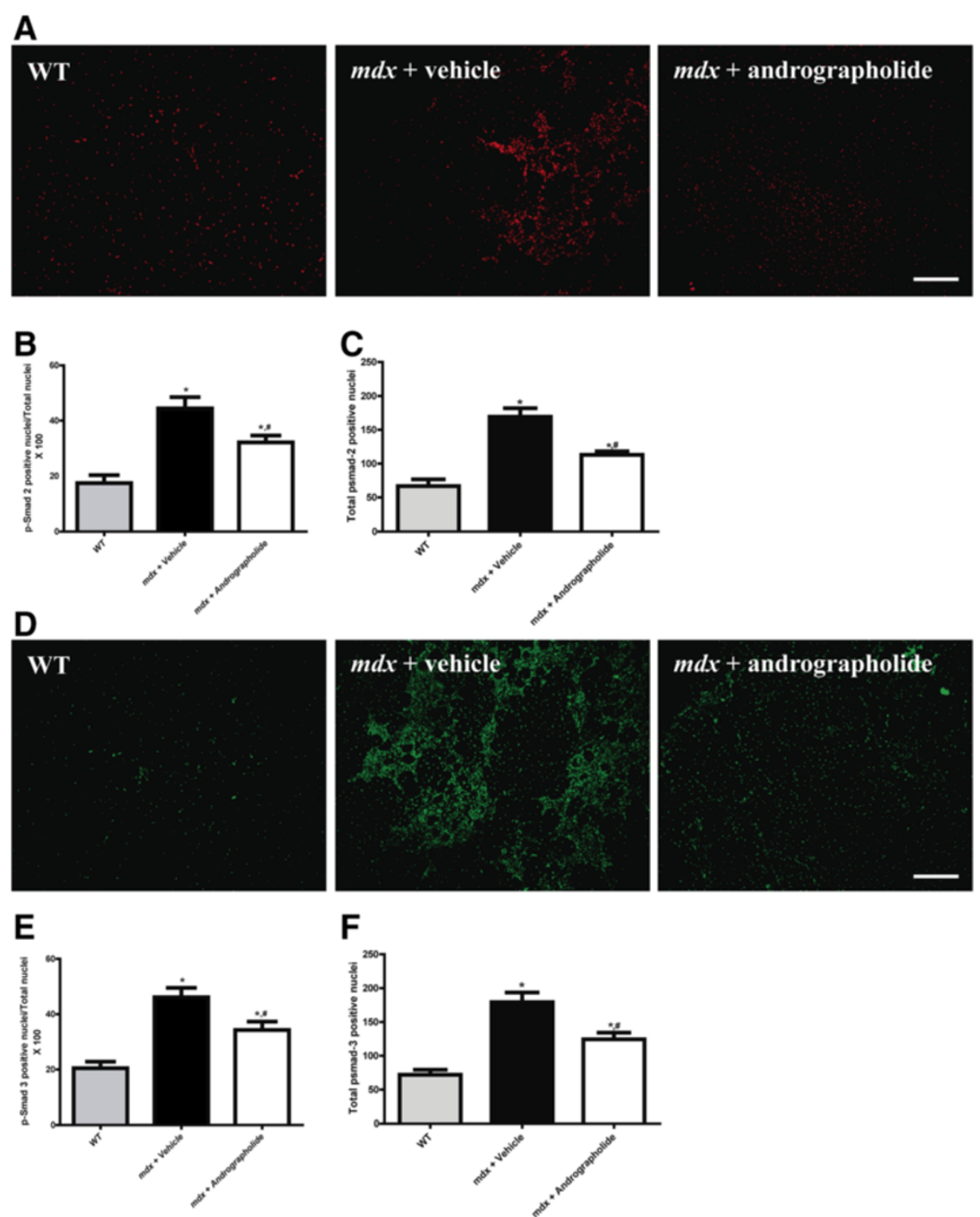

Figure 6 Andrographolide reduces transforming growth factor type beta (TGF- $\beta$ ) signaling pathway activity in $m d x$ mice. Indirect immunofluorescence analysis of (A) p-Smad-2 and (D) p-Smad-3 (intracellular TGF- $\beta 1$ mediators) in cryosections of tibialis anterior (TA) muscle from vehicle-treated and andrographolide-treated $m d x$ mice. Bar corresponds to $200 \mu \mathrm{m}$. (B,E) Ratio of p-Smad-2 and p-Smad-3 respectively versus total nuclei. (C,F) Quantification of total nuclei per field (in 400X magnification pictures). Values are expressed as mean \pm SD of three independent experiments, using three mice for each experimental condition.

month-old $m d x$ mice following pre-treatment with either andrographolide or vehicle for a three-month period under an exercise protocol. Treatment with andrographolide was stopped one week before the transplantation to rule out any direct effect of the drug on the transplanted cells. One month after the satellite cell transplantation, the muscle was analyzed for the presence of dystrophin-positive myofibers and the amount of collagen I. Figure 8 shows that the number of dystrophin-positive fibers in the $m d x$ background was increased three-fold in the andrographolidetreated mice compared with controls (Figure 8A and B). Moreover, Figure $8 \mathrm{~A}$ shows the expected reduction in collagen I content following andrographolide treatment. The purity of the transplanted cells was determined prior to the graft by plating an aliquot of the cells on ECM gel for 12 hours and analyzing expression of the musclespecific transcription factors Pax7, MyoD, and myogenin. Over $92 \%$ of the nuclei were positive for at least one of these factors, indicating the purity of the preparation (data not shown). To evaluate if andrographolide treatment has an effect on the size of endogenous satellite cells, the number of satellite cells present on isolated EDL myofibers obtained from the same transplanted mice was determined, with a mean of 12.5 satellite cells per EDL myofiber as 

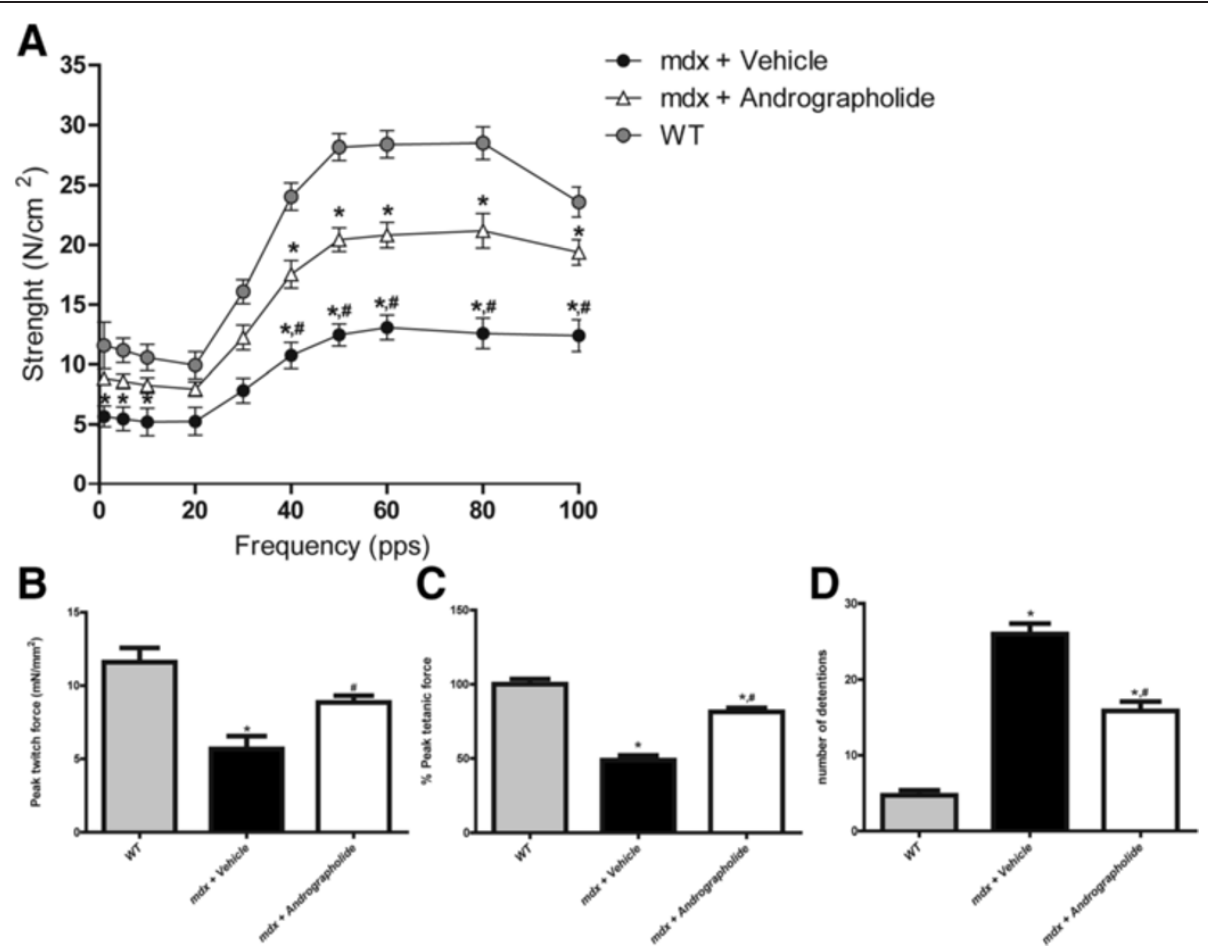

Figure 7 Andrographolide increases skeletal muscle strength in $\mathbf{m} \boldsymbol{d x}$ mice. Fibrosis was augmented as explained in the legend of Figure 1. During this period, mice were treated with $1 \mathrm{mg} / \mathrm{kg}$ andrographolide or vehicle (intraperitoneal (ip) injections three times per week, six animals per group). (A) Tibialis anterior (TA) muscles were isolated from wild type (WT), vehicle-treated $m d x$ mice, and andrographolide-treated $m d x$ mice to evaluate isometric specific force $(\mathrm{mN} / \mathrm{mm} 2)$ at different stimulation frequencies (pulses per second, pps). (B) Bar graph shows tetanic specific force. Values are represented as percentage of specific isometric force generated by WT muscle $\left({ }^{*} P<0.05\right.$ relative to WT mice; $\# P<0.05$ relative to vehicle-treated $m d x$ mice). The recovery score for the twitch force measurement was $54.2 \%$. (C) Bar graph showing twitch force $\left({ }^{*} P<0.05\right.$ relative to WT mice; $\# P<0.05$ relative to vehicle-treated $m d x$ mice). The recovery score for the tetanus measurement was $50.3 \%$. (D) Mice were subjected to an exercise challenge on the treadmill at 15 meters/minute for five minutes and the number of set-backs was counted $\left(n=7,{ }^{*} P<0.05\right.$ relative to WT mice; $\# P<0.05$ relative to vehicle-treated $m d x$ mice). The recovery score for this measurement was $45.5 \%$.

shown in Figure 8C, suggesting than andrographolide treatment did not affect the size of satellite cell populations. Finally the number of cells engrafted was determined as a function of time. Figure 8D, indicates that the number of transplanted cells increase with time. This increase is dramatically augmented in muscle TA obtained from mouse pre-treated with andrographolide, suggesting a higher rate of survival of the grafted cells. These results strongly suggest that andrographolide treatment of $m d x$ mice improves the efficiency of cell therapy.

\section{Discussion}

In this paper, we show that andrographolide treatment reduced skeletal muscle damage and fibrosis in $m d x$ mice. We observed that this reduction was associated with an increase in muscle functionality. Moreover, we showed that the improved skeletal muscle phenotype of dystrophic mice favored the incorporation of dystrophin-positive muscle cells after intramuscular injection of satellite cells derived from WT skeletal muscle. To the best of our knowledge, this is the first report of the use of andrographolide on a model of muscular dystrophy.
Several anti-fibrotics have been tested to decrease fibrosis associated to dystrophic skeletal muscle [43]. Among them neutralizing antibodies against all three forms of TGF- $\beta$ importantly reduced hydroxyproline levels and plasma creatine kinase, improved respiratory function and grip strength [44]. Halofunginone has been tested in $m d x$ mice, reducing collagen content and improving respiratory and heart function. It has been suggested that it inhibits p-Smad-3 in response to TGF- $\beta 1$ [45-47]. The use of inhibitors and antagonists of the renin-angiotensin system have been shown to decrease fibrosis and improve skeletal muscle function [48]. Infusion of angiotensin 1-7, which signals through the Mas receptor, has been shown to importantly decrease fibrosis, TGF- $\beta$ mediated signaling and increase skeletal muscle strength [49]. It is difficult to compare which of these drugs, including andrographolide, have a better effect on dystrophic skeletal muscle, since some of them may also have other undesired side effects. Furthermore, the same readouts are not always determined in each case. Nevertheless a comparative study, under the same experimental conditions would be very valuable. 

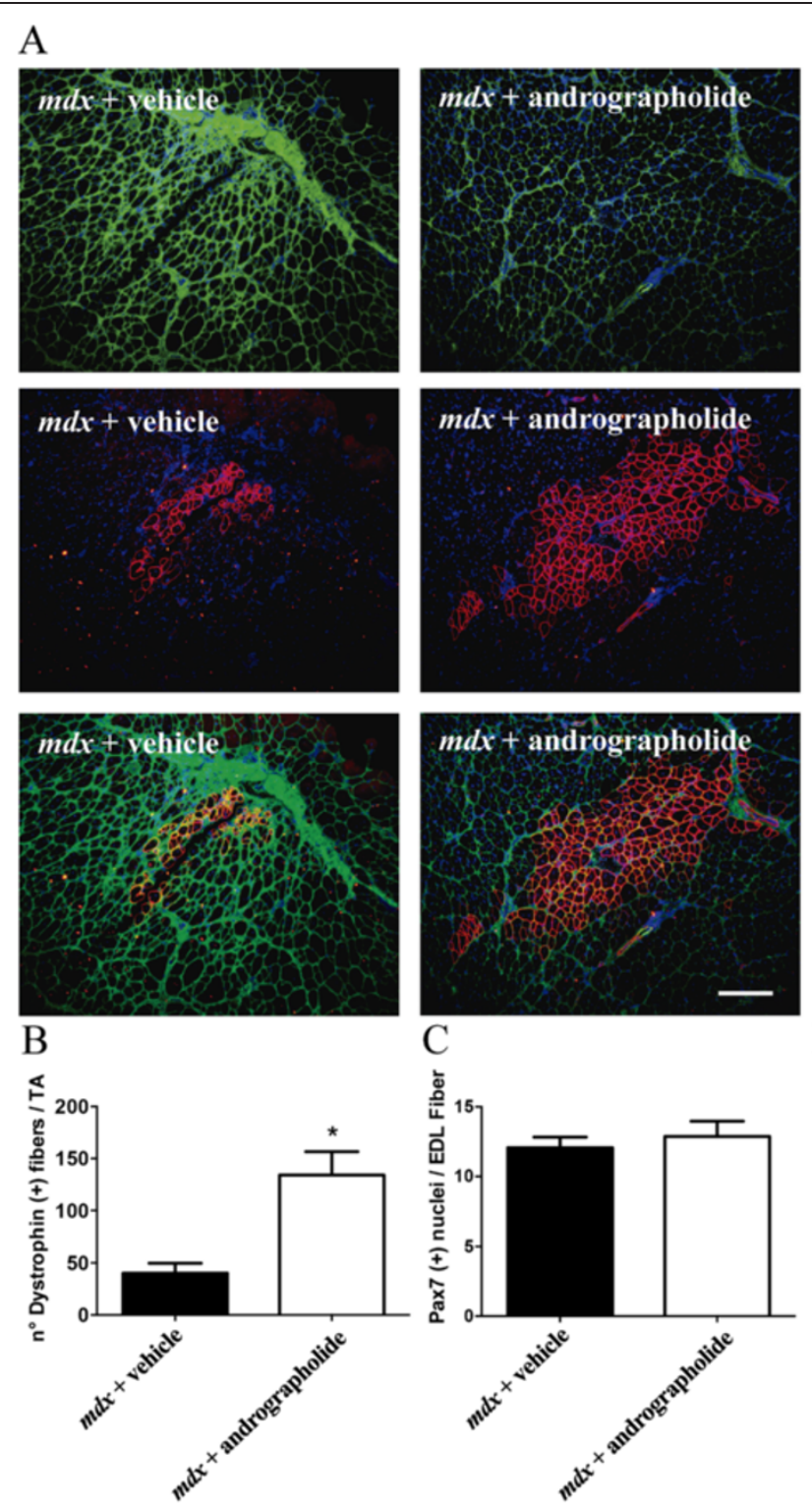

\section{D}

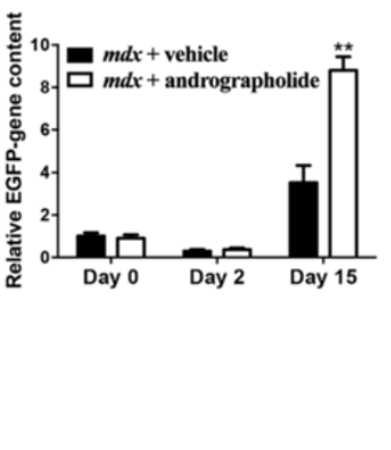

Figure 8 Muscle stem cell therapy with satellite cells (SC) is improved by the reduction in muscle fibrosis following treatment with andrographolide. (A) Fibrosis was augmented as explained in the legend of Figure 1. During this period, mice were treated with andrographolide or vehicle (intraperitoneal (ip) injections three times per week, six animals per group). One week after the last drug administration (seven-monthold mice), 500 freshly isolated satellite cells purified from wild type (WT) mice were transplanted into both tibialis anterior (TA) muscles of each mdx mouse. At four weeks after engraftment, the number of fibers expressing dystrophin and collagen I was determined by immunofluorescence analysis of cryosections. The images are representative of two experimental groups with six mice per group. Bar corresponds to $200 \mu \mathrm{m}$. (B) Quantification of the data obtained in (A) showing the number of myofibers expressing dystrophin per TA muscle in each case. (C) The number of satellite cells (PAX-7-positive nuclei) was determined for isolated single muscle fibers from extensor digitorum longus muscle (EDL) of each case as an indicator of endogenous SC survival. (D) 500 WT SC freshly isolated as in (A), from the C57-EGFP mice were engrafted in mice treated as in (A) (six animals per group). Both TA muscles were dissected immediately after engraftment or after 2 or 15 days from two animals in each case. Total genomic DNA was purified. EGFP transgene present in the engrafted muscle was detected by qPCR. Values are expressed as mean \pm SD of three independent experiments. ( ${ }^{*} \mathrm{P}<0.05$ relative to vehicle-treated mice, ${ }^{* *} \mathrm{P}<0.01$ relative to vehicle-treated mice at day 15$)$.

Corticosteroids are currently the most effective treatment for DMD [50-52]. They act by blocking transcription factors such as NF- $\mathrm{kB}$ and AP-1 to down-regulate a vast group of pro-inflammatory genes. However, the use of corticosteroids is associated with unwanted side effects and a significant proportion of patients are steroidresistant [52], therefore there is an urgent need to develop novel anti-inflammatory drugs to replace or complement current therapy. In this study, we have preliminary data that indicate that parallel treatment with prednisone 
or andrographolide in $m d x$ three-month-old animals for three months produce the same histological improvement together with a decrease in the amount of collagen (Additional file 4: Figure S4).

Andrographolide has been used in acute and chronic diseases such as the common cold and rheumatoid arthritis with no observable side effects (for a review, see reference [53]). Therefore, it is reasonable to consider the use of alternative treatments such as andrographolide to improve skeletal muscle physiology in patients suffering from skeletal muscular dystrophies such as DMD. Although our findings suggest that andrographolide might be used to improve quality of life in individuals with DMD, the effectiveness of andrographolide in other skeletal muscle dystrophies requires further investigation. Extrapolation of studies in small animals, such as mice, to clinical treatment of humans can be very difficult. The use of andrographolide as shown in this paper is promising because andrographolide has been used alone or as a botanical extract for the treatment of colds, fever, laryngitis and other infections with no or minimal side effects. Andrographolide not only regulates inflammation, but also suppresses the fibrotic pathology observed in chronic liver and kidney diseases [14-16]. Other advantages include the low cost of the drug, or a botanical extract highly enriched in andrographolide, and the fact that it can be given orally in capsules, thus providing hope for future therapeutic options of an oral formulation with no undesired side effects for patients with muscular disorders.

Fibrosis is one of the main features of dystrophic muscle. A high increase in ECM deposition is found in biopsies from DMD patients and in different animal models of the disease [4,39,54,55]. Although enormous efforts have been made to restore dystrophin expression in DMD patients through different approaches, such as gene and cell therapies, it has been proposed that fibrosis is an important barrier to the success of these approaches [9,21,56-58]. Therefore, targeting fibrosis is an important strategy to generate an environment that facilitates cell migration and regeneration in the dystrophic muscle. This is supported by a report that local injection of fibroblasts secreting metalloproteinases reduced collagen deposition, thereby allowing efficient subsequent therapy with intraarterial injection of WT mesoangioblasts in dystrophic muscles [21], and the observation that models with reduced activity of a pro-fibrotic growth factor showed an increase in the number of grafted dystrophin-positive skeletal muscle fibers in $m d x$ muscle [6].

Different experimental approaches have been attempted to decrease fibrosis in dystrophic muscle and other myopathies $[59,60]$. One of the main pro-fibrotic cytokines is TGF- $\beta$, therefore blocking TGF- $\beta$ promotes histological recovery of muscle tissue and also significantly decreases the levels of ECM proteins, thus promoting and increasing muscular functionality $[41,60,61]$. In the same way, our results show that inhibition of fibrosis is correlated with a decrease in TGF- $\beta$. Furthermore, our results showed that andrographolide treatment inhibited the TGF- $\beta$ canonical signaling pathway, as evidenced by a reduced number of nuclei positive for the key TGF- $\beta$ intracellular mediators p-Smad-2 and p-Smad-3. The decrease seems to affect, in higher proportion, interstitial cells than regenerating fibers. These observations suggest a novel mechanism of the action for andrographolide.

Andrographolide is an anti-inflammatory molecule that acts through specific inhibition of NF- $k B$. NF- $k B$ predominantly functions as a heterodimer of p65 and p50, in which p65 contains the transactivation domain and p50 is involved in the recognition of NF- $\mathrm{kB}$ DNA element responses. It has been reported that andrographolide inhibits NF- $\mathrm{kB}$ by covalent binding with a cysteine residue in the $\mathrm{p} 50$ subunit, thus inhibiting the binding of NF- $\kappa B$ to DNA [17]. Contrary to our report, $m d x$ mice heterozygous for the p50 subunit do not present any significant histological changes; however, $m d x$ mice heterozygous for the p65 subunit present a mild dystrophic phenotype [18]. A probable explanation is that p50 bound to andrographolide sequesters the p65 subunits thus preventing transactivation activity of this protein on target genes. However, this hypothesis needs to be confirmed.

Moreover, we showed that the inhibition of fibrosis by andrographolide correlates with a decrease in TGF- $\beta$ and CTGF expression. Both growth factors can directly induce fibrosis in skeletal muscle and specific reduction of either of them improves the dystrophic phenotype in $m d x$ mice $[6,40]$. It is known that TGF- $\beta$ is a strong inducer of CTGF activity [7,42,62]. Furthermore, it has been shown that CTGF strongly synergizes with TGF- $\beta$ to induce fibrosis [63]. CTGF expression requires $\mathrm{NF}-\mathrm{kB}$ activity because the CTGF promoter contains a functional and specific NF- $\mathrm{kB}$ response element [64]. Therefore, is plausible that andrographolide down-regulates CTGF expression through inhibition of NF- $\mathrm{kB}$ because andrographolide decreased NF- $\mathrm{kB}$ activity in vivo.

\section{Conclusions}

In conclusion, our preclinical evaluation of andrographolide in a mouse model of DMD showed promising improvements in dystrophic skeletal muscles by preventing damage and fibrosis progression. The reduction of fibrosis was associated with enhanced muscle strength and increased efficiency of cell therapy.

\section{Additional files}

Additional file 1: Figure S1. TA fiber diameter in $m d x$ mice is not affected by andrographolide treatment. Minimal Feret's diameters were determined in muscle cross- sections from WT, $m d x$ mice treated with vehicle, and mdx mice treated with andrographolide. Fiber diameters were grouped from 0 to 
$100 \mu \mathrm{m}$. The images are representative of three independent experiments, using four mice for each experimental condition.

Additional file 2: Figure S2. Andrographolide improves skeletal muscle morphology and reduces the amount of collagen I in $m d x$ skeletal muscles. (A) Fibrosis was augmented as explained in the legend of Figure 1. During this period, mice were treated with $1 \mathrm{mg} / \mathrm{kg}$ andrographolide or vehicle (ip injections three times per week, six animals per group). H\&E staining and indirect immunofluorescence analysis of collagen I (green) in cryosections of gastrocnemius muscles from vehicle-treated $m d x$ mice and andrographolide-treated $m d x$ mice are shown in the upper and the bottom panel respectively. (B) Nonexercised mice were treated with $1 \mathrm{mg} / \mathrm{kg}$ andrographolide or vehicle (ip injections three times per week, six animals per group). H\&E staining and indirect immunofluorescence analysis of collagen I (green) in cryosections of diaphragm muscles from vehicle-treated $m d x$ mice and andrographolide-treated $m d x$ mice are shown in the upper and the bottom panel respectively. Bar corresponds to $50 \mu \mathrm{m}$. Nuclei are stained in blue (Hoechst).

Additional file 3: Figure S3. Andrographolide mainly reduces TGF- $\beta$ signaling pathway activity in necrotic and regeneration foci in $m d x$. Upper panel shows an indirect immunofluorescence analysis of p-Smad-3 (red), to localize the positive nuclei, the membranes were labeled with wheat germ agglutinin (green) and the nuclei are stained in blue (Hoechst). Bottom panel shows consecutive sections stained with H\&E. Bar corresponds to $200 \mu \mathrm{m}$.

Additional file 4: Figure S4. Andrographolide or prednisone treatment improves skeletal muscle histology and decreases collagen content to some extent in $m d x$ skeletal muscles. Fibrosis was augmented as explained in the legend of Figure 1. During this period, mice were treated with $1 \mathrm{mg} / \mathrm{kg}$ andrographolide or with $5 \mathrm{mg} / \mathrm{kg}$ prednisone (both drugs were administered orally twice weekly on consecutive days). The figure shows an indirect immunofluorescence analysis of collagen I (green) in cryosections of TA muscles from vehicle-treated $m d x$ mice, andrographolide-treated $m d x$ mice and prednisone-treated $m d x$ mice. Nuclei are stained in blue (Hoechst). Bar corresponds to $50 \mu \mathrm{m}$.

\section{Abbreviations}

ANOVA: one-way analysis of variance; BSA: bovine serum albumin; CK: creatine kinase; Col: collagen; CSA: cross-sectional area; CTGF/ CCN2: connective tissue growth factor; DIG: digoxigenin; DMD: Duchenne Muscular Dystrophy; DMEM: Dulbecco's modified Eagle's medium; EBD: Evans blue dye; ECM: extracellular matrix; EDL: extensor digitorum longus; FN: fibronectin; H\&E: hematoxylin-eosin staining; ip: intraperitoneal; NF-KB: nuclear factor kappa-light-chain-enhancer of activated B cells; PBS: phosphate-buffered saline; qPCR: quantitative real-time polymerase chain reaction; SC: satellite cells; TA: tibialis anterior; TGF- $\beta$ : transforming growth factor type beta; WT: wild type.

\section{Competing interests}

The authors declare that they have no competing interests.

\section{Authors' contributions}

DC carried out the andrographolide experiments in mice, participated in the sequence alignment and drafted the manuscript. JG carried out the grafting assays. CC-V participated in TGF- $\beta$ analysis. MGM participated in the CTGF analysis. SM participated in the NF-KB analysis. JCC, RF and JH participated in the discussion of the design of the experiments. EB conceived of the study, and participated in its design and coordination and helped to draft the manuscript. All authors read and approved the final manuscript.

\section{Acknowledgements}

This study was supported by research grants from CARE PFB12/2007. FONDEF: D0711051, VIU 110070. FONDECYT: 1110426, 11110010, 1120380, 3140396, 3130593. CONICYT: Graduate student scholarship (DC), AT-24091098, 79090027. Fundación Chilena para Biología Celular Proyecto MF-100. Association-Française Contre Les Myopathies AFM 16670. UNAB-DI-281-13/R.

\section{Author details}

'Centro de Regulación Celular y Patología (CRCP), Centro de Regeneración y Envejecimiento (CARE), Laboratorio de Diferenciación Celular y Patología, Departamento de Biología Celular y Molecular, MIFAB, Pontificia Universidad Católica de Chile, Avenida Libertador Bernardo O'Higgins, 340, Santiago, Chile. ${ }^{2}$ Departamento de Ciencias Químicas y Biológicas, Universidad Bernardo O'Higgins, Santiago, Chile. ${ }^{3}$ Laboratorio de Biología y Fisiopatología Molecular, Departamento de Ciencias Biológicas, Facultad de Ciencias Biológicas \& Facultad de Medicina, Universidad Andrés Bello, Santiago, Chile. ${ }^{4}$ División de Nefrología, Escuela de Medicina, Universidad Austral, Valdivia, Chile. ${ }^{5}$ Departamento de Neurología, Facultad de Medicina, Pontificia Universidad

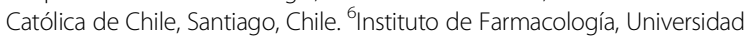
Austral de Chile, Valdivia, Chile.

Received: 22 October 2013 Accepted: 26 February 2014 Published: 21 March 2014

\section{References}

1. Kapsa R, Kornberg AJ, Byrne E: Novel therapies for Duchenne muscular dystrophy. Lancet Neurol 2003, 2:299-310.

2. Blau HM, Webster C, Pavlath GK: Defective myoblasts identified in Duchenne muscular dystrophy. Proc Natl Acad Sci USA 1983, 80:4856-4860

3. Allen DG, Whitehead NP: Duchenne muscular dystrophy - what causes the increased membrane permeability in skeletal muscle? Int J Biochem Cell Biol 2011, 43:290-294.

4. Alvarez K, Fadic R, Brandan E: Augmented synthesis and differential localization of heparan sulfate proteoglycans in Duchenne muscular dystrophy. J Cell Biochem 2002, 85:703-713.

5. Wynn TA: Cellular and molecular mechanisms of fibrosis. J Pathol 2008, 214:199-210.

6. Morales MG, Gutierrez J, Cabello-Verrugio C, Cabrera D, Lipson KE, Goldschmeding R, Brandan E: Reducing CTGF/CCN2 slows mdx muscle dystrophy and improves cell-therapy. Hum Mol Genet 2013, 22:4938-4951.

7. Brandan E, Gutierrez J: Role of proteoglycans in the regulation of the skeletal muscle fibrotic response. FEBS J 2013, 280:4109-4117.

8. Varga J, Brenner DA, Phan SH: Fibrosis Research: Methods and Protocols. Totowa, NJ: Humana Press; 2005:392.

9. Zhou L, Lu H: Targeting fibrosis in Duchenne muscular dystrophy. J Neuropathol Exp Neurol 2010, 69:771-776.

10. Desquerre I, Mayer M, Leturcq F, Barbet JP, Gherardi RK, Christov C: Endomysial fibrosis in Duchenne muscular dystrophy: a marker of poor outcome associated with macrophage alternative activation J Neuropathol Exp Neurol 2009, 68:762-773.

11. Shen YC, Chen CF, Chiou WF: Andrographolide prevents oxygen radical production by human neutrophils: possible mechanism(s) involved in its anti-inflammatory effect. Br J Pharmacol 2002, 135:399-406.

12. Rajagopal S, Kumar RA, Deevi DS, Satyanarayana C, Rajagopalan R: Andrographolide, a potential cancer therapeutic agent isolated from Andrographis paniculata. J Exp Ther Oncol 2003, 3:147-158.

13. Calabrese C, Berman SH, Babish JG, Ma X, Shinto L, Dorr M, Wells K, Wenner CA, Standish LJ: A phase I trial of andrographolide in HIV positive patients and normal volunteers. Phytother Res 2000, 14:333-338.

14. Lee TY, Lee KC, Chang HH: Modulation of the cannabinoid receptors by andrographolide attenuates hepatic apoptosis following bile duct ligation in rats with fibrosis. Apoptosis 2010, 15:904-914.

15. Lee MJ, Rao YK, Chen K, Lee YC, Chung YS, Tzeng YM: Andrographolide and 14-deoxy-11,12-didehydroandrographolide from Andrographis paniculata attenuate high glucose-induced fibrosis and apoptosis in murine renal mesangial cell lines. J Ethnopharmacol 2010, 132:497-505.

16. Ye JF, Zhu H, Zhou ZF, Xiong RB, Wang XW, Su LX, Luo BD: Protective mechanism of andrographolide against carbon tetrachloride-induced acute liver injury in mice. Biol Pharm Bull 2011, 34:1666-1670

17. Xia YF, Ye BQ, Li YD, Wang JG, He XJ, Lin X, Yao X, Ma D, Slungaard A, Hebbel RP, Key NS, Geng JG: Andrographolide attenuates inflammation by inhibition of NF-kappa B activation through covalent modification of reduced cysteine 62 of p50. J Immunol 2004, 173:4207-4217. 
18. Acharyya S, Villalta SA, Bakkar N, Bupha-Intr T, Janssen PM Carathers M, Li ZW, Beg AA, Ghosh S, Sahenk Z, Weinstein M, Gardner KL, Rafael-Fortney JA, Karin M, Tidball JG, Baldwin AS, Guttridge DC: Interplay of IKK/NF-kappaB signaling in macrophages and myofibers promotes muscle degeneration in Duchenne muscular dystrophy. J Clin Invest 2007, 117:889-901.

19. Peterson JM, Guttridge DC: Skeletal muscle diseases, inflammation, and NF-kappaB signaling: insights and opportunities for therapeutic intervention. Int Rev Immunol 2008, 27:375-387.

20. Peterson JM, Kline W, Canan BD, Ricca DJ, Kaspar B, Delfín DA, DiRienzo K, Clemens PR, Robbins PD, Baldwin AS, Flood P, Kaumaya P, Freitas M, Kornegay JN, Mendell JR, Rafael-Fortney JA, Guttridge DC, Janssen PM: Peptide-based inhibition of NF-kappaB rescues diaphragm muscle contractile dysfunction in a murine model of Duchenne muscular dystrophy. Mol Med 2011, 17:508-515.

21. Gargioli C, Coletta M, De Grandis F, Cannata SM, Cossu G: PIGF-MMP-9expressing cells restore microcirculation and efficacy of cell therapy in aged dystrophic muscle. Nat Med 2008, 14:973-978.

22. Rowland LP: Pathogenesis of muscular dystrophies. Arch Neurol 1976, 33:315-321.

23. De Luca A, Pierno S, Liantonio A, Cetrone M, Camerino C, Fraysse B, Mirabella M, Servidei S, Ruegg UT, Conte Camerino D: Enhanced dystrophic progression in $\mathrm{mdx}$ mice by exercise and beneficial effects of taurine and insulin-like growth factor-1. J Pharmacol Exp Ther 2003, 304:453-463.

24. De Luca A, Nico B, Liantonio A, Didonna MP, Fraysse B, Pierno S, Burdi R, Mangieri D, Rolland JF, Camerino C, Zallone A, Confalonieri P, Andreetta F, Arnoldi E, Courdier-Fruh I, Magyar JP, Frigeri A, Pisoni M, Svelto $\mathrm{M}$, Conte Camerino D: A multidisciplinary evaluation of the effectiveness of cyclosporine a in dystrophic mdx mice. Am J Pathol 2005, 166:477-489.

25. Cabello-Verrugio C, Morales MG, Cabrera D, Vio CP, Brandan E: Angiotensin II receptor type 1 blockade decreases CTGF/CCN2-mediated damage and fibrosis in normal and dystrophic skeletal muscles. $J$ Cell Mol Med 2012, 16:752-764.

26. Morales MG, Cabello-Verrugio C, Santander C, Cabrera D, Goldschmeding R, Brandan E: CTGF/CCN-2 over-expression can directly induce features of skeletal muscle dystrophy. J Pathol 2011, 225:490-501.

27. Grounds MD, Torrisi J: Anti-TNFalpha (Remicade) therapy protects dystrophic skeletal muscle from necrosis. FASEB J 2004, 18:676-682

28. Grounds MD, Radley HG, Lynch GS, Nagaraju K, De Luca A: Towards developing standard operating procedures for pre-clinical testing in the mdx mouse model of Duchenne muscular dystrophy. Neurobiol Dis 2008 31:1-19.

29. Straub V, Rafael JA, Chamberlain JS, Campbell KP: Animal models for muscular dystrophy show different patterns of sarcolemmal disruption. J Cell Biol 1997, 139:375-385.

30. Hernandez-Presa MA, Gomez-Guerrero C, Egido J: In situ non-radioactive detection of nuclear factors in paraffin sections by Southwestern histochemistry. Kidney Int 1999, 55:209-214

31. Morales MG, Cabrera D, Cespedes C, Vio CP, Vazquez Y, Brandan E, Cabello-Verrugio C: Inhibition of the angiotensin-converting enzyme decreases skeletal muscle fibrosis in dystrophic mice by a diminution in the expression and activity of connective tissue growth factor (CTGF/CCN-2). Cell Tissue Res 2013, 353:173-187.

32. Villalta SA, Rinaldi C, Deng B, Liu G, Fedor B, Tidball JG: Interleukin-10 reduces the pathology of $\mathrm{mdx}$ muscular dystrophy by deactivating $M 1$ macrophages and modulating macrophage phenotype. Hum Mol Genet 2011, 20:790-805.

33. Gregorevic P, Plant DR, Leeding KS, Bach LA, Lynch GS: Improved contractile function of the $\mathrm{mdx}$ dystrophic mouse diaphragm muscle after insulin-like growth factor-I administration. Am J Pathol 2002, 161:2263-2272.

34. Barton ER, Morris L, Kawana M, Bish LT, Toursel T: Systemic administration of L-arginine benefits mdx skeletal muscle function. Muscle Nerve 2005, 32:751-760

35. Bogdanovich S, McNally EM, Khurana TS: Myostatin blockade improves function but not histopathology in a murine model of limb-girdle muscular dystrophy 2C. Muscle Nerve 2008, 37:308-316.
36. Collins CA, Olsen I, Zammit PS, Heslop L, Petrie A, Partridge TA, Morgan JE: Stem cell function, self-renewal, and behavioral heterogeneity of cells from the adult muscle satellite cell niche. Cell 2005, 122:289-301.

37. Gillis JM: Multivariate evaluation of the functional recovery obtained by the overexpression of utrophin in skeletal muscles of the $\mathrm{mdx}$ mouse. Neuromuscul Disord 2002, 12(Suppl 1):S90-S94.

38. Radley HG, Davies MJ, Grounds MD: Reduced muscle necrosis and long-term benefits in dystrophic mdx mice after cV1q (blockade of TNF) treatment. Neuromuscul Disord 2008, 18:227-238

39. Caceres S, Cuellar C, Casar JC, Garrido J, Schaefer L, Kresse H, Brandan E: Synthesis of proteoglycans is augmented in dystrophic mdx mouse skeletal muscle. Eur J Cell Biol 2000, 79:173-181.

40. Andreetta F, Bernasconi P, Baggi F, Ferro P, Oliva L, Arnoldi E, Cornelio F, Mantegazza R, Confalonieri P: Immunomodulation of TGF-beta 1 in $\mathrm{mdx}$ mouse inhibits connective tissue proliferation in diaphragm but increases inflammatory response: implications for antifibrotic therapy. J Neuroimmunol 2006, 175:77-86.

41. Cohn RD, van Erp C, Habashi JP, Soleimani AA, Klein EC, Lisi MT, Gamradt M, ap Rhys CM, Holm TM, Loeys BL, Ramirez F, Judge DP, Ward CW, Dietz HC: Angiotensin II type 1 receptor blockade attenuates TGF-beta-induced failure of muscle regeneration in multiple myopathic states. Nat Med 2007, 13:204-210.

42. Vial C, Zuniga LM, Cabello-Verrugio C, Canon P, Fadic R, Brandan E: Skeletal muscle cells express the profibrotic cytokine connective tissue growth factor (CTGF/CCN2), which induces their dedifferentiation. J Cell Physiol 2008, 215:410-421

43. De Luca A: Pre-clinical drug tests in the mdx mouse as a model of dystrophinopathies: an overview. Acta Myol 2012, $31: 40-47$

44. Nelson CA, Hunter RB, Quigley LA, Girgenrath S, Weber WD, McCullough JA, Dinardo CJ, Keefe KA, Ceci L, Clayton NP, McVie-Wylie A, Cheng SH, Leonard JP, Wentworth BM: Inhibiting TGF-beta activity improves respiratory function in $\mathrm{mdx}$ mice. Am J Pathol 2011, 178:2611-2621.

45. Huebner KD, Jassal DS, Halevy O, Pines M, Anderson JE: Functional resolution of fibrosis in $\mathrm{mdx}$ mouse dystrophic heart and skeletal muscle by halofuginone. Am J Physiol Heart Circ Physiol 2008, 294:H1550-H1561.

46. Turgeman T, Hagai Y, Huebner K, Jassal DS, Anderson JE, Genin O, Nagler A, Halevy O, Pines M: Prevention of muscle fibrosis and improvement in muscle performance in the $\mathrm{mdx}$ mouse by halofuginone. Neuromuscul Disord 2008, 18:857-868.

47. Pines $M$, Halevy $O$ : Halofuginone and muscular dystrophy. Histol Histopathol 2011, 26:135-146.

48. MacDonald EM, Cohn RD: TGFbeta signaling: its role in fibrosis formation and myopathies. Curr Opin Rheumatol 2012, 24:628-634

49. Acuna MJ, Pessina P, Olguin H, Cabrera D, Vio CP, Bader M, Munoz-Canoves P, Santos RA, Cabello-Verrugio C, Brandan E: Restoration of muscle strength in dystrophic muscle by angiotensin-1-7 through inhibition of TGF-beta signalling. Hum Mol Genet 2014, 23:1237-1249.

50. Wehling-Henricks M, Lee JJ, Tidball JG: Prednisolone decreases cellular adhesion molecules required for inflammatory cell infiltration in dystrophin-deficient skeletal muscle. Neuromuscul Disord 2004, 14:483-490

51. Hoffman EP, Reeves E, Damsker J, Nagaraju K, McCall JM, Connor EM, Bushby K: Novel approaches to corticosteroid treatment in Duchenne muscular dystrophy. Phys Med Rehabil Clin N Am 2012, 23:821-828.

52. Wong BL, Christopher C: Corticosteroids in Duchenne muscular dystrophy: a reappraisal. J Child Neurol 2002, 17:183-190.

53. Lim JC, Chan TK, Ng DS, Sagineedu SR, Stanslas J, Wong WS: Andrographolide and its analogues: versatile bioactive molecules for combating inflammation and cancer. Clin Exp Pharmacol Physiol 2012, 39:300-310.

54. Cabello-Verrugio C, Acuna MJ, Morales MG, Becerra A, Simon F, Brandan E: Fibrotic response induced by angiotensin-II requires $\mathrm{NAD}(\mathrm{P}) \mathrm{H}$ oxidase-induced reactive oxygen species (ROS) in skeletal muscle cells. Biochem Biophys Res Commun 2011, 410:665-670. 
55. Mezzano V, Cabrera D, Vial C, Brandan E: Constitutively activated dystrophic muscle fibroblasts show a paradoxical response to TGF-beta and CTGF/CCN2. J Cell Commun Signal 2007, 1:205-217.

56. Li G, Xie Q, Shi Y, Li D, Zhang M, Jiang S, Zhou H, Lu H, Jin Y: Inhibition of connective tissue growth factor by siRNA prevents liver fibrosis in rats. J Gene Med 2006, 8:889-900.

57. Guha M, Xu ZG, Tung D, Lanting L, Natarajan R: Specific down-regulation of connective tissue growth factor attenuates progression of nephropathy in mouse models of type 1 and type 2 diabetes. FASEB $J$ 2007, 21:3355-3368.

58. Klingler W, Jurkat-Rott K, Lehmann-Horn F, Schleip R: The role of fibrosis in Duchenne muscular dystrophy. Acta Myol 2012, 31:184-195.

59. Leask $A$, Abraham DJ: TGF-beta signaling and the fibrotic response. FASEB J 2004, 18:816-827.

60. Ng CM, Cheng A, Myers LA, Martinez-Murillo F, Jie C, Bedja D, Gabrielson KL, Hausladen JM, Mecham RP, Judge DP, Dietz HC: TGF-beta-dependent pathogenesis of mitral valve prolapse in a mouse model of Marfan syndrome. J Clin Invest 2004, 114:1586-1592.

61. Fukushima K, Badlani N, Usas A, Riano F, Fu F, Huard J: The use of an antifibrosis agent to improve muscle recovery after laceration. $\mathrm{Am} J$ Sports Med 2001, 29:394-402.

62. de Winter $\mathrm{P}$, Leoni $\mathrm{P}, \mathrm{Abraham} \mathrm{D}$ : Connective tissue growth factor: structure-function relationships of a mosaic, multifunctional protein. Growth Factors 2008, 26:80-91.

63. Wang Q, Usinger W, Nichols B, Gray J, Xu L, Seeley TW, Brenner M, Guo G, Zhang W, Oliver N, Lin A, Yeowell D: Cooperative interaction of CTGF and TGF-beta in animal models of fibrotic disease. Fibrogenesis Tissue Repair 2011, 4:4.

64. Chaqour B, Yang R, Sha Q: Mechanical stretch modulates the promoter activity of the profibrotic factor CCN2 through increased actin polymerization and NF-kappaB activation. J Biol Chem 2006, 281:20608-20622.

doi:10.1186/2044-5040-4-6

Cite this article as: Cabrera et al:: Andrographolide attenuates skeletal muscle dystrophy in $m d x$ mice and increases efficiency of cell therapy by reducing fibrosis. Skeletal Muscle 2014 4:6.

\section{Submit your next manuscript to BioMed Central and take full advantage of:}

- Convenient online submission

- Thorough peer review

- No space constraints or color figure charges

- Immediate publication on acceptance

- Inclusion in PubMed, CAS, Scopus and Google Scholar

- Research which is freely available for redistribution 